Louisiana State University

LSU Digital Commons

Faculty Publications

Department of Oceanography \& Coastal

Sciences

$9-1990$

\title{
Relationships Between Wetland Fragmentation and Recent Hydrologic Changes in a Deltaic Coast
}

\author{
R. Eugene Turner \\ euturne@lsu.edu \\ Yeleswarapu S. Rao
}

Follow this and additional works at: https://digitalcommons.Isu.edu/oceanography_coastal_pubs

\section{Recommended Citation}

Turner, R., \& Rao, Y. S. (1990). Relationships Between Wetland Fragmentation and Recent Hydrologic Changes in a Deltaic Coast. Estuaries, 13 (3), 272-281. Retrieved from https://digitalcommons.Isu.edu/ oceanography_coastal_pubs/157

This Article is brought to you for free and open access by the Department of Oceanography \& Coastal Sciences at LSU Digital Commons. It has been accepted for inclusion in Faculty Publications by an authorized administrator of LSU Digital Commons. For more information, please contact ir@lsu.edu. 


\title{
Relationships Between Wetland Fragmentation
}

\section{and Recent Hydrologic Changes}

\section{in a Deltaic Coast}

\author{
R. EugEne Turner \\ Coastal Ecology Institute \\ Center for Wetland Resources \\ Louisiana State University \\ Baton Rouge, Louisiana 70803 \\ Yeleswarapu S. Rao \\ Department of Computer Sciences \\ Louisiana State University \\ Baton Rouge, Louisiana 70803
}

\begin{abstract}
Patterns in coastal wetland loss in the northern Gulf of Mexico were examined using aerial imagery from 1955-56 and 1978. Five qualitative types of wetland changes are evident: (1) spoil bank-parallel pond formation, (2) pond formation with apparent random distribution for the smallest ponds, but very clumped distribution for larger ponds, (3) semi- or complete impoundment resulting in open water formation, (4) cutting off of stream channels upstream of where a spoil bank crosses a natural channel, and (5) erosion at the land-water interface. Only ponds $<20$ ha formed and disappeared in the interval, and it is clear that wetland breakup, not erosion at the pond-lake edge, is the dominant form of wetland-to-open water conversion. Canals and their spoil banks are spatially related to wetland-to-water conversion which is evident up to $\mathbf{2} \mathbf{~ k m}$ away from those man-made features. The indirect impacts of canals and spoil banks vary regionally, for example, with sediment compaction rates that increase with increasing sediment deposition. These results are consistent with the hypothesis that canals and spoil banks are a major factor driving wetland loss rates because they change wetland hydrology.
\end{abstract}

\section{Introduction}

The well-documented and severe wetland loss rates in coastal Louisiana $(0.86 \%$ annually or 288,414 ha from 1955-56 to 1978; Baumann and Turner In press) have been attributed to both natural and man-induced causes (Craig et al. 1980; Scaife et al. 1983; Turner 1985; Turner and Cahoon 1987; Walker et al. 1987). The coastal zone, built over 7,000 years by a series of six major deltaic episodes, has gradually lowered through the combined effects of global sea level rise and the sinking of land caused by sediment compression, de-watering, and a geosynclinal shift in the basement material. Both sediments and plant materials must accumulate at the surface to compensate for this subsidence. But, the supply and distribution of sediments, organic materials, and plants is not stable in recent time. Suspended sediments in the Mississippi River have apparently declined by $50 \%$ since the early 1950s (Meade and Parker 1985; Kesel 1988) and an extensive man-made levee system within the wetlands has altered the natural hydrology (Swenson and Turner 1987) and, concomitantly, sediment distributions and soil chemistry.
Further, the flood-protection levees along the lower Mississippi River reduce overbank flooding, except at the river's terminus. The hydrologic patterns associated with building these wetlands, and which now sustain the plants and sediments holding it together, has changed as $7 \%$ of the wetlands were converted into canal and spoil banks (built mainly for oil and gas recovery operations). It is not clear how much or how quickly the landscape can adjust to such perturbations.

Analysis of landscape changes is useful to test hypotheses about the relative influence and interaction of various proposed causal factors that lead to wetland-to-open water conversions. It is readily observed that wetlands do not disappear without first disintegrating; wetlands fragment as they turn into open water. It is the result of this fragmentation into small and then larger open water bodies that we studied here. We wanted to know how the distribution of new open water bodies, or ponds in the marsh, was related to the geologic framework, time for development, and to dredge-and-fill activities, principally canals and their associated spoil banks. We examined (1) the distribution and sizes 
of new water bodies or "holes" in the marsh from 1955-56 to 1978 and (2) the distances from these ponds to natural and certain man-made hydrologic influences, particularly canals and their associated spoil banks.

\section{Methods and Materials}

We used digitized habitat maps for coastal Louisiana stored in the Geographical Information System (GIS) in the Data General computer at the Louisiana Department of Natural Resources (DNR), Baton Rouge, Louisiana. The GIS has the habitat data for our study areas in the form of 244 7.5-minute quadrangle maps (each map is approximately 41,000 acres or 16,600 hectares) for $1955-$ 56 and 1978. Habitats on these maps are described by the habitat codes of Cowardin et al. (1979) and classified by Wicker $(1980,1981)$.

The digitized data can be viewed, extracted, and analyzed with the aid of a Map Overlays and Statistical System (MOSS, version 8509) interactive graphics software developed and updated under the direction of the U.S. Bureau of Land Management. Further information about MOSS can be obtained from the Bureau of Land Management, Division of Advanced Data Technology, Branch of Technology Applications and Assistance, Bldg. 50, Denver Federal Center, P.O. Box 25047, Denver, Colorado 80225-0047.

The maps stored in the GIS are permanent, that is, they are write-protected to protect data integrity. Because grouping the habitat codes on these original maps into different categories is not possible, maps from GIS were copied to another directory, renamed, and their access control list (ACL) and permanence rules changed. This procedure enabled any user to group the habitat codes into desirable categories using the ASSIG program available on the system (written by Decision Associates, Inc., 1276 Sharynwood Drive, Baton Rouge, Louisiana 70808). Appropriate "macro" routines were developed for the MOSS to simplify and speed up the operations on the Data General Computer. Hard copies of the maps were plotted on the Versatec Plotter (Model 7224; 200 dots per inch) and some were re-entered into a personal computer program to be used as examples below.

The habitat codes were grouped into seven categories-open water, upland, wetlands, canals, levees, area out of coastal zone, and "unassigned"to determine area and percent of the total. The category unassigned represents the habitat codes which do not signify anything, were unidentifiable, or were misrepresented while digitizing; these areas amount to less than $0.001 \%$ of coastal Louisiana.

The open water category was subdivided into ponds in the ranges of $0-20$ ha $(0-50$ acres $), 20-$
40 ha (50-100 acres), 40-50 ha (100-150 acres), and $>60$ ha $(>150$ acres). We also mapped ponds in the $0-8,8-20$, and $20-60$ ha size range to use for discussion purposes. The number and range of these size classes were chosen before analysis after visual inspection of all the habitat maps, field experience, and examination of the aerial imagery. The minimum range was chosen knowing (1) that the standard error of measurement increases with decreasing size of the mapped unit, and (2) that a 20 -ha pond is equivalent to $0.125 \%$ of the 7.5 minute map, or a square of about $19 \times 19 \mathrm{~mm}$ actual measuring distance on the original photographs.

We obtained maps and information for seventytwo 1955-56 and 1978 habitat maps. For each pair of maps the plots showing the ponds in each size range was compared and the new, persistent and transient ponds were distinguished. New ponds are ponds not existing in the 1955-56 map, but found in the 1978 map. Ponds found in both the 195556 and 1978 maps were termed persistent ponds. Ponds found in the 1955-56 map, but not in the 1978 map, were termed transient ponds.

The analysis of pond distribution was done considering the fact that two or more ponds in the lower size range could have merged between mapping intervals causing the original pond to disappear from the lower size range of ponds and therefore appear as a new pond in the higher size range of ponds. Also, it is possible for a pond in the higher size range to have disintegrated between 1955-56 and 1978 , causing it to disappear from the higher size range and appear as a new pond in the lower size range. We did not keep records of either possibilities, but believe it occurred in less than $1 \%$ of all ponds less than 20 ha. Such discrepancies were closely scrutinized and not included in the analysis.

We determined the distribution of new ponds in the vicinity of the canals for 72 map pairs. All three pond types (new, persistent, and transient) of each size range were counted as a function of distance to a canal present in 1955-56 and/or 1978, for distances up to $4.2 \mathrm{~km}$ from the canal (the distance was chosen on the basis of a preliminary analysis of effects versus distance). All the new ponds $<20$ ha within $1 \mathrm{~km}$ of the $1955-56$ and 1978 canals were also counted. Distance was measured by hand from the canal water edge to the nearest part of the pond-water interface. We used four different map groupings: the Chenier Plain, the St. Bernard delta, the Barataria and Terrebonne hydrologic units, and those maps containing the Mississippi River Gulf outlet (MRGO; Fig. 1). These correspond to the same groupings in Cowan and Turner (1989), with the exception of the additional group of maps including portions of MRGO. The cre- 


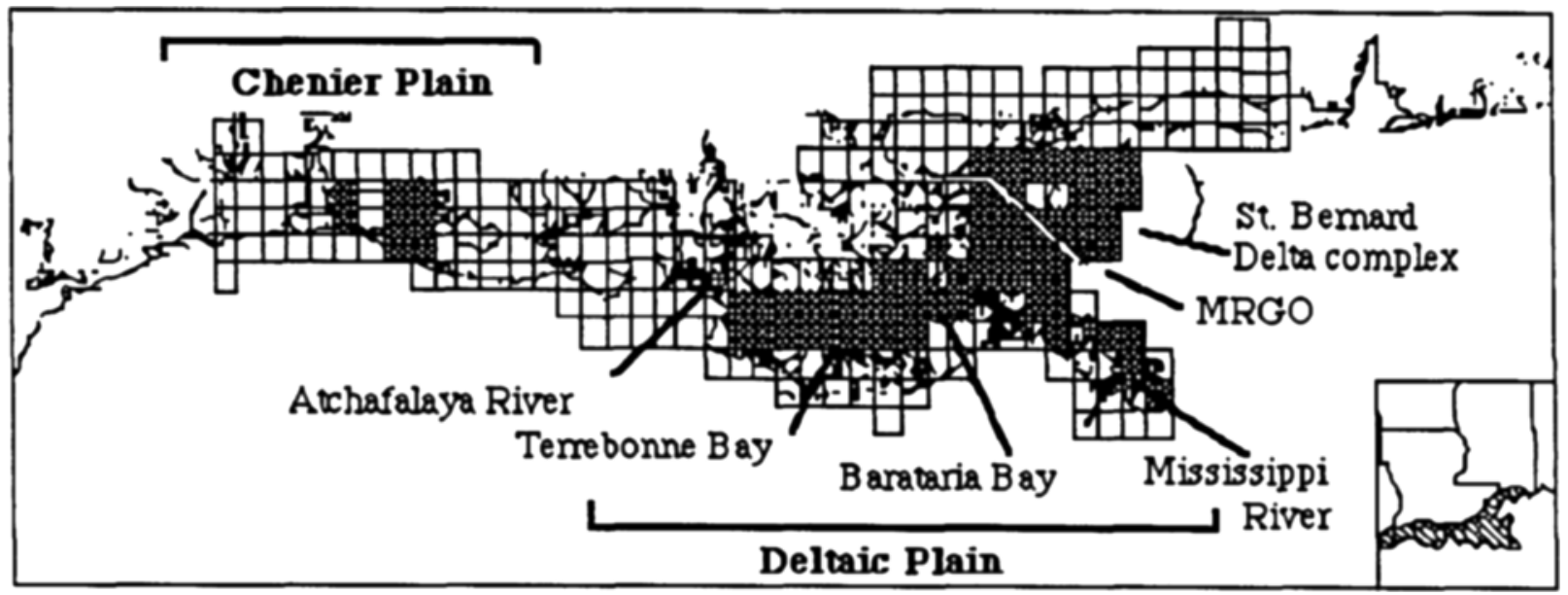

Fig. 1. The study area, showing quadrangle maps; the shaded areas indicate quadrangle maps used in analyses.

ation of this latter map group is justified on the basis of the unusual length and width of this manmade channel (it extends across the St. Bernard subdelta from the Gulf of Mexico to New Orleans) and because the channel is dredged frequently for ocean-going barges and most of the dredged spoil is placed on the western side of the channel.

All together, $38 \%$ of the coastal wetland loss from $1955-56$ to 1978 in the Louisiana coastal zone is represented in these map pairs. About $10.5 \%$ of this wetland loss was due to an increase in canal surface between 1955-56 and 1978. Because we were interested primarily in the relationships between hydrologic changes and wetland losses and not interested the effects of wetland reclamation, data used for open water changes vs. canal area relationship determination were omitted from portions of the analysis when: (1) map data were clearly entered incorrectly (one map), (2) significant urbanization or agricultural development occurred (six maps), or (3) pre-1955-56 agricultural impoundments were evident (two maps).

All linear regression analyses are significant at the $95 \%$ level, or higher.

\section{Results \\ Qualitative Changes}

Some general features of the observed diversity of landscape change were apparent and are presented here. These features involve changes in the types of open water bodies formed, their location with regard to spoil banks and canals, and, apparent changes in natural hydrology. We will use a few maps for examples.

Virtually all maps have a higher number of the smallest ponds $(0-20 \mathrm{ha})$ relative to the other pond sizes. An example is shown for Mink Bayou (Fig.
2) where the number of ponds $0-20$ ha is especially numerous, and the number declines with increasing pond size. Fewer transient ponds were observed than persistent ones. Many of the ponds were either parallel to canals/spoil banks or had an apparent hydrologic connection leading directly to a canal.

The smaller new ponds appeared to be clustered near canals, and the association became more pronounced as the pond size increased. The larger ponds were most often clustered next to a canal (quantified below), especially, it appeared, when the pond was bordered on two or more sides by a canal. We did not estimate the degree of enclosure of ponds by canals, because of the lack of resources and ideas to precisely evaluate the degree of "enclosure" efficiently and objectively. A few examples are shown in Fig. 3 using four quadrangle maps depicting new ponds 20-60 ha (in black) and canals (straight lines). These four quadrangle maps were mostly wetland in 1955-56, except for the Bastian Bay quadrangle map, whose southwestern quadrant was open water. The Mink Bayou (previous figure), Golden Meadow, and Bastian Bay maps show the clumping of new ponds (of this size) next to the canals, and often where canals come together. The Cutoff map, in contrast, had no ponds form of that size, despite the presence of many canals. The only pond to form in the entire Larose map area, otherwise wetland, was next to a canal.

The largest new water bodies were occasionally the apparent consequence of impounding the wetland with a man-made levee. A particularly clear example of this was in the Cutoff quadrangle map (Fig. 4). An agricultural impoundment of the early part of this century (Turner and Neill 1984) apparently failed at some point, and the wetland vegetation present in 1955-56 was no longer present 


\section{$0-8$ ha}

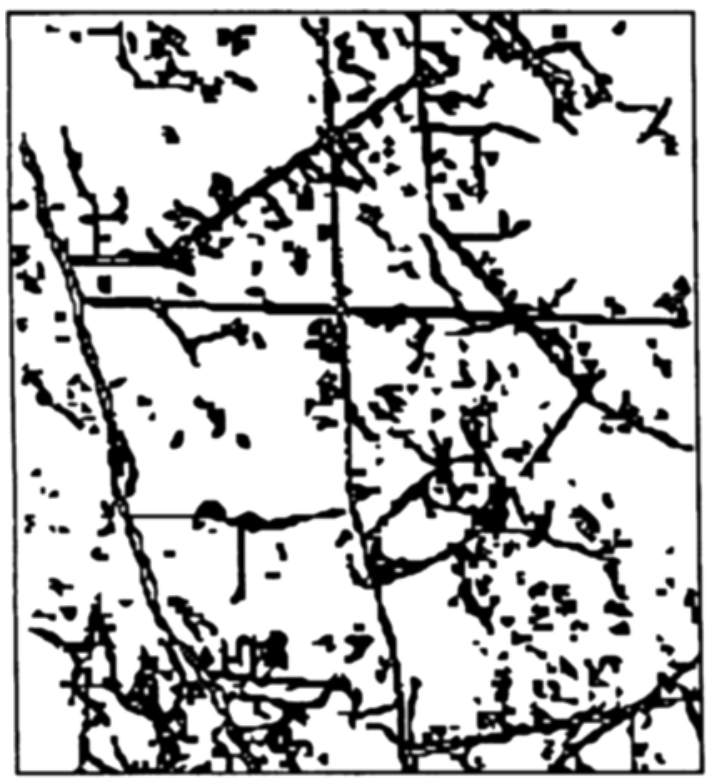

20-60 ha

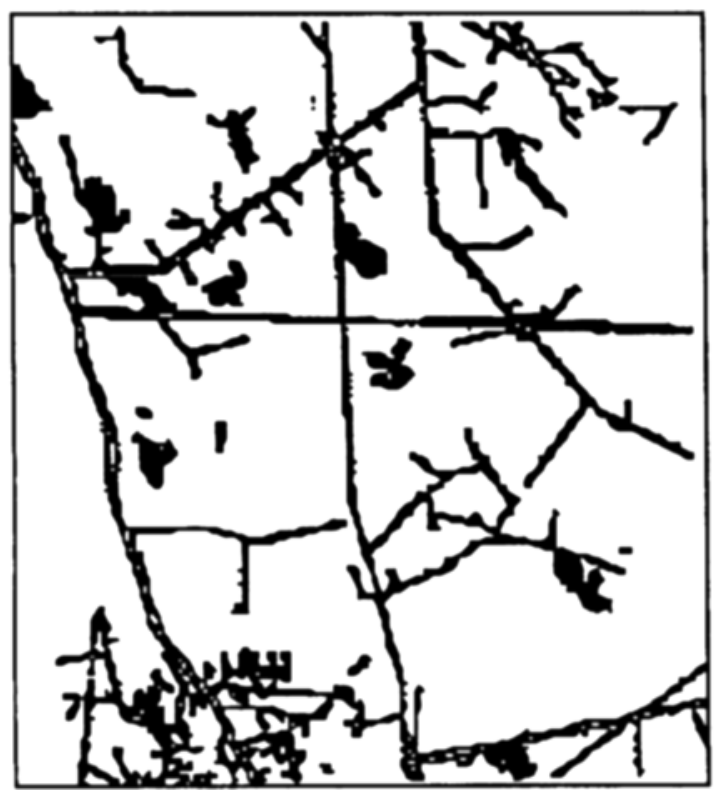

8-20 ha

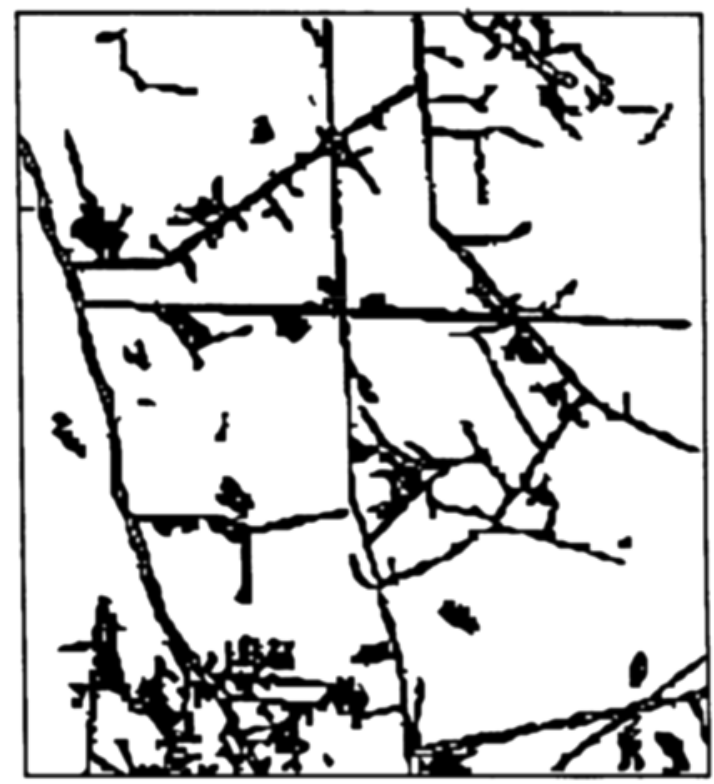

$>60$ ha

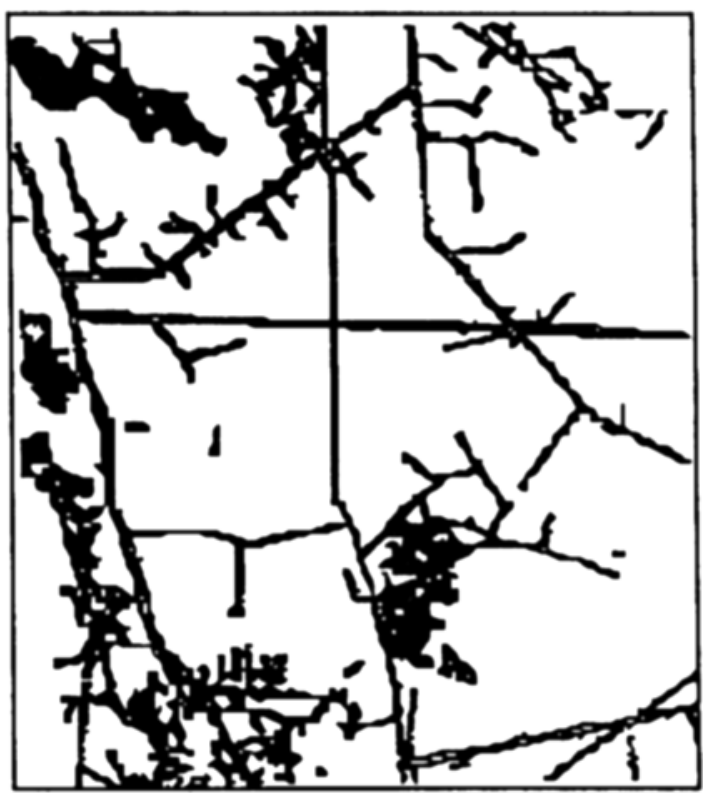

Fig. 2. The wetland loss as ponds (in black) in the Mink Bayou quadrangle map from 1956-1978. Four different pond sizes are shown. Canals present in 1978 are the straight, dark lines.

in 1978 , as it had turned to open water. Ninetynine percent of all of the wetland loss (1,359 ha) in this quadrangle map was inside the impoundment. Such examples taught us to examine each map for unusual circumstances leading to wetland loss.

We often observed that the natural stream chan- nel network seemed to disappear when canals and spoil banks blocked tidal exchange. The upstream, not the downstream, channel was more likely to disappear. These observations are supported by Craig et al. (1980) who measured a logarithmic decrease in natural stream density with a linear increase in canal density for $1-\mathrm{km}$ square grids 

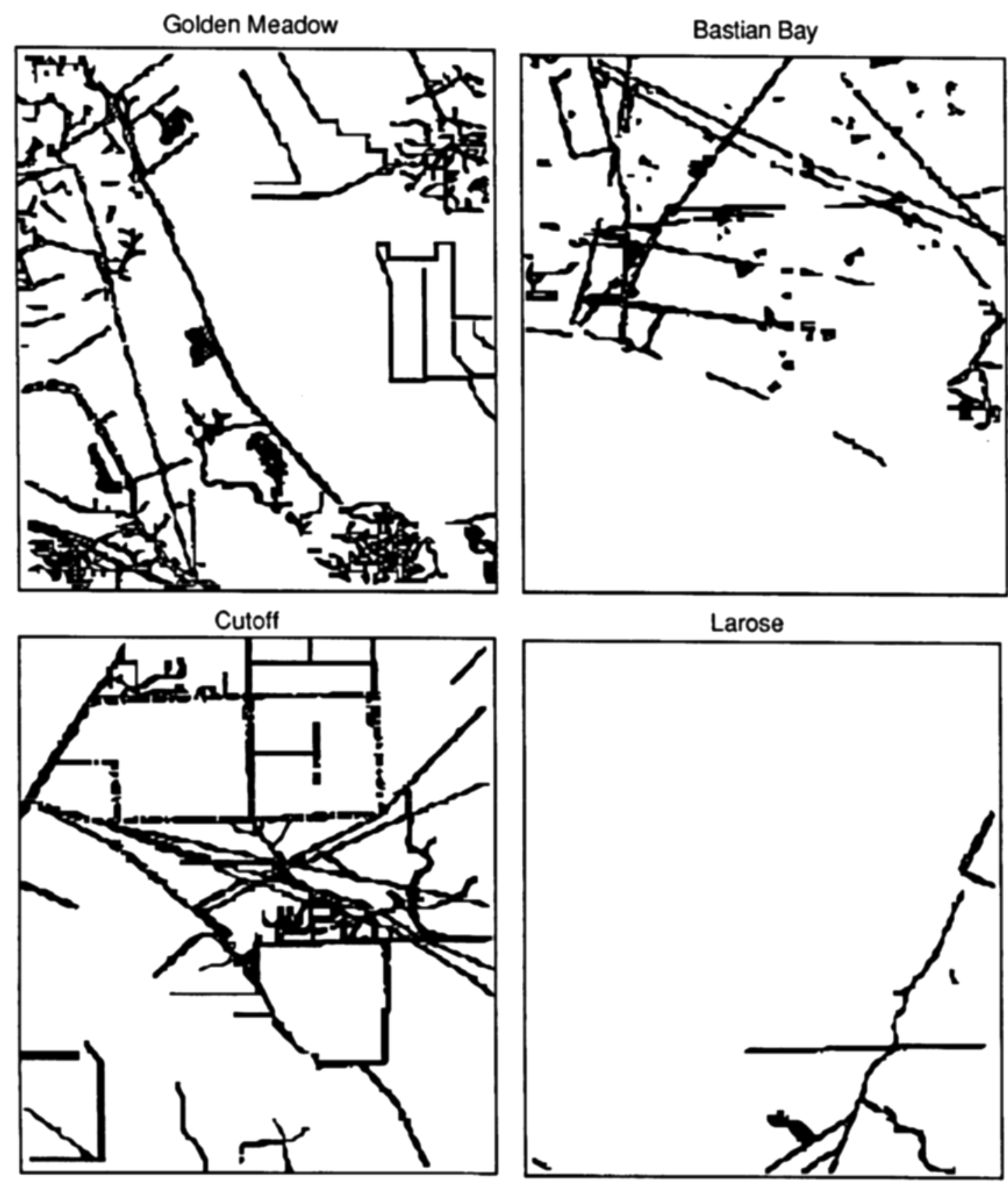

Fig. 3. The wetland loss from $1955-56$ to 1978 as ponds $20-60$ ha (in black) for four quadrangle maps in the Barataria hydrologic unit. Canals present in 1978 are the straight dark lines.

around Leeville, Louisiana. Photograph examples are in Turner (1985).

\section{QuANTIFIED RELATIONSHIPS}

The distribution of all new, persistent, and transient ponds within $4.2 \mathrm{~km}$ from a 1978 canal is shown for all the ponds in Fig. 5. No standard deviations are depicted since all ponds in each map were included in the analysis.
New ponds between 0 and 20 ha are 6 times more numerous than all other pond sizes combined. The numerical distribution of the new $0-20$ ha ponds with distance from a canal is not the same as for ponds classified as persistent or transient (Fig. 5). Two patterns are evident. First, the percent of the new and persistent ponds are distributed coincidentally and decrease with distance away from the canal. The distribution of transient ponds, in con- 


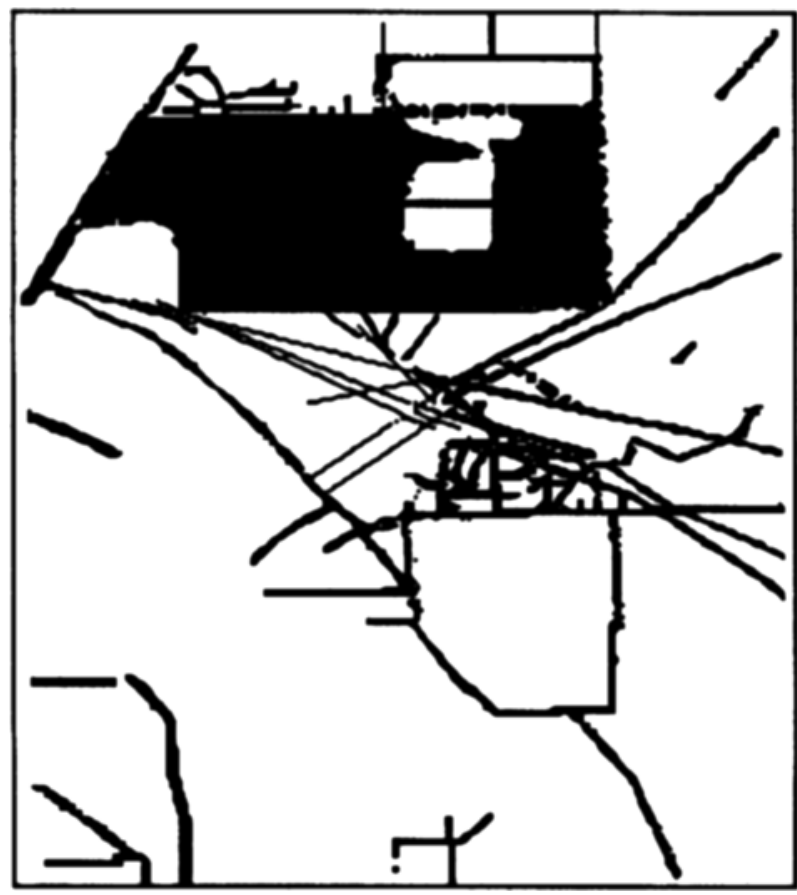

Fig. 4. The wetland loss (in black) from 1956-1978 as ponds $>60$ ha for the Cutoff quadrangle map. Canals present in 1978 are the straight dark lines. Dashed lines are canals present in 1956 but not mapped in 1978. One massive pond formed in the map area, but no where else.

trast, is relatively lower near the canal. Forty percent of new and persistent ponds are within 0.4 $\mathrm{km}$ from a canal, compared to $15 \%$, or less, for the transient ponds. Second, the percent of transient ponds does not peak nearest the canal, but peaks at about 1.0 to $1.5 \mathrm{~km}$ from the canal, and then declines with distance either away from or toward a canal. The distribution of new, persistent and transient ponds declines to near zero percent several $\mathrm{km}$ from the canal. Clearly something about the canals and spoil banks, or something related to them, influences pond formation and disappearance; if otherwise, the percent distribution of all three pond types within $2 \mathrm{~km}$ from a canal would be similar, and probably would reflect the percent of marsh with distance from a canal. These results are not a consequence of mapping errors because the cartographers had no a priori information to distinguish between new, persistent, and transient ponds of any size.

The new and persistent ponds of 20-40 ha are located much closer to the canal than the ponds < 20 ha. At least $75 \%$ of the ponds $20-40$ ha occurred within $0.4 \mathrm{~km}$ of a canal, which is nearly twice the percentage of the $0-20$ ha ponds. This difference is not simply a consequence of measuring from the canal to the pond edge, rather than the middle of
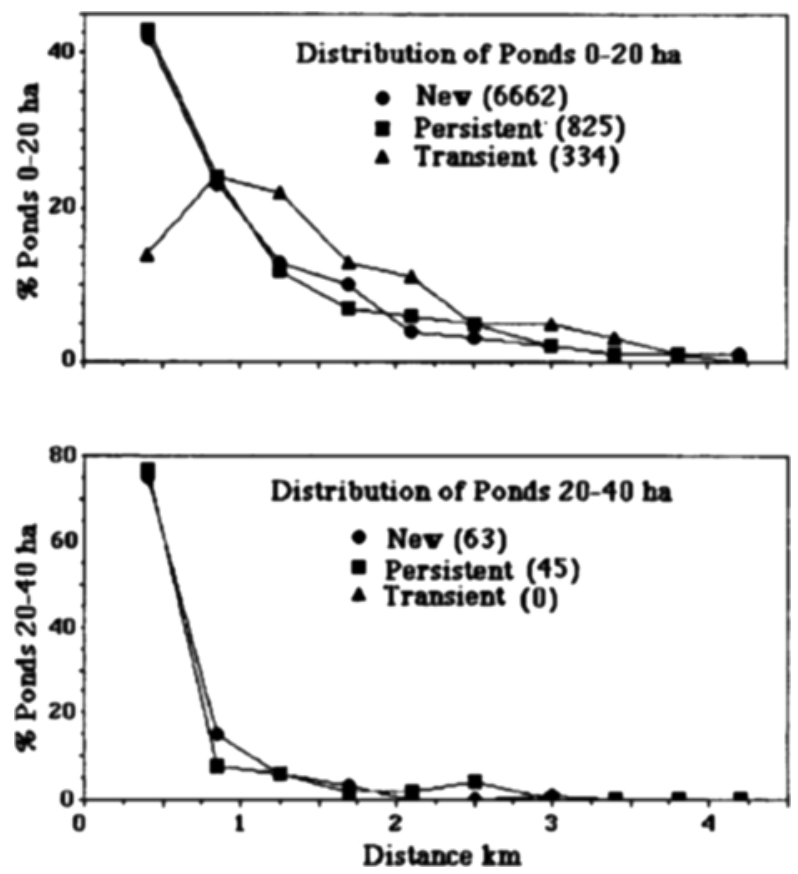

Fig. 5. The distribution of new, persistent and transient ponds $<20$ ha and between 20 and 40 ha within $4.2 \mathrm{~km}$ distance from 1978 canals. Zero distance is at the canal edge. The data are for 10 equal-sized distance classes. The number of ponds in each category is in parentheses.

the pond, although the apparent effect may be slightly exaggerated because of our methods. For example, a square 30 -ha pond would be only 0.24 $\mathrm{km}$ closer, than a 10-ha pond, if both were measured from the center of the pond. Ninety-five percent of all new 20-40 ha size ponds were within 1 $\mathrm{km}$ of the canal edge, compared to $2.5 \mathrm{~km}$ for the $0-20$ ha size ponds. No transient ponds $20-50$ ha, or larger, were mapped in the entire study site (ponds were not considered transient if they enlarged). If the 0-20 ha and 20-40 ha new ponds were randomly distributed and not influenced by canals and spoil banks, then their distributions should be similar; they are not.

What happened to the area and number of smaller ponds was representative of changes in the larger ponds (Fig. 6). If the area of ponds between 0 and 20 ha increased from 1955-56 to 1978, then the area of ponds in the other size classes was also likely to increase. The slope of a linear regression between net pond areal growth for ponds of different sizes was always positive (significant at the $5 \%$ level) with one exception (for $0--20$ vs. $20-40$ ha ponds in the quadrangle maps including the Mississippi River channel). Regional differences were apparent in the relationship between these two variables. These results lend credence to the view that factors influencing the distribution and 

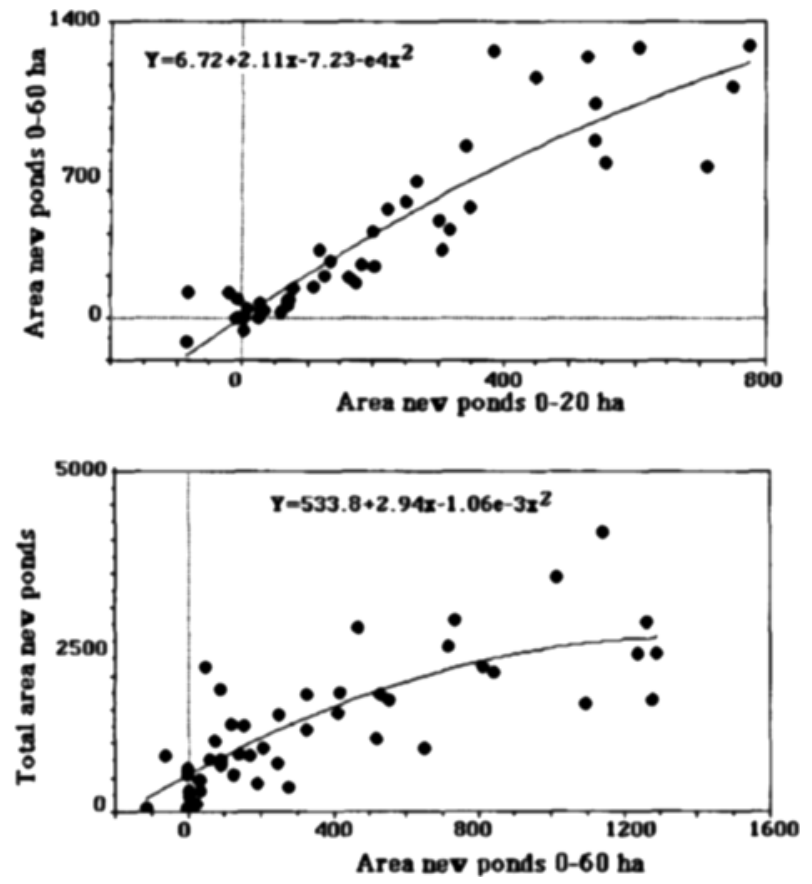

Fig. 6. The relationship between the area of new ponds $0-$ 60 ha and $0-20$ ha (upper panel) and between the total area of new ponds and new ponds $0-60$ ha.

number of ponds $0-20$ ha also influence the geographical distribution of all ponds within a quadrangle map.

For two reasons, we used both the number of the new ponds $0-20$ ha and the total area of new ponds $0-60$ ha to investigate the relationship between wetland loss (i.e., pond formation) and canal density. We examined areal relationships by using the area of new ponds in the category $0-60 \mathrm{ha}$, since the area of new $0-60$ ha size ponds is generally related to the total area of new ponds of all sizes (e.g., Fig. 6). However, there are fewer ponds in each size category as the pond size increases. We therefore also used the number of the smallest ponds in a second analysis.

There was a positive relationship between area and number of new ponds formed and canal area for four study regions, but not for the Chenier Plain which had a relatively smaller range in values (Figs. 7 and 8 ). The statistically significant slopes were similar for the St. Bernard, Barataria, and Terrebonne maps, but lowest in the map group with a portion of MRGO in them. Maps combined from all areas except the MRGO maps also had a significant relationship between the two variables. For each map the slopes are positive and the Y-intercept is near zero when canal density is zero.

\section{Discussion}

At least five qualitative types of wetland changes are evident in these maps of 22-yr changes: (1) spoil bank-parallel pond formation, (2) pond formation with apparent random distribution for the smallest ponds and clumped distribution for the largest ponds, (3) semi- or complete impoundment and resulting open water formation, (4) cutting off of stream channels upstream of where a spoil bank crosses a natural channel, and (5) erosion at the land-water interface. Only ponds $<20$ ha appear to form and disappear. This last result might be considered to be due to mapping errors; however, the large number of transient ponds $10 \%$ of the total), a different distribution of the transient ponds compared to the new ponds, and mapping of smaller features contributes to strong arguments against accepting such biases as meaningful complications. An examination of these maps of new ponds in the marsh clearly shows that marsh fragmentation in the wetland interior dominates over erosion at the shoreline. We have made similar observations of individual marshes over more frequent intervals.

Coastwide, the ponds $0-60$ ha are equal to $50 \%$ of the gains in open water during the mapping interval. The losses are not randomly distributed, but clumped in areas of high and low wetland-toopen water conversion rates, as others have previously observed (e.g., Craig et al. 1980; Scaife et al. 1983). The non-random distribution is spatially related to hydrologic changes, for example, canals and spoil banks.

New small ponds are more numerous than persistent and transient water bodies of the same size. New pond area and the number of small ponds are directly related to the area and number of larger ponds; if new small ponds form, it is likely that the less numerous larger ponds will also form. These patterns are also consistent with the conclusion that the marsh is literally breaking up internally, as much as it is eroding at the edge. The relationship between small and larger pond number is less clear as pond size increases. This situation probably reflects, in part, the lower frequency of the larger ponds, hence the smaller statistical base to work with. But, it also may reflect the regional (outside the quadrangle map) influence of geologic factors, canal and spoil banks, as well as agricultural impoundments (e.g., Fig. 4), urbanization, navigation channels, and local sediment sources. An analysis of areas of particularly high or low wetland loss was also useful to understand regional differences or anomalous conditions (e.g., in the Cutoff quadrangle). These other influences contribute to the variability in the relationships between wetland loss and hydrologic changes (as represented by the area of canal density). For example, Scaife et al. (1983) showed that land loss within these same 7.5-minute quadrangle maps was partially related to the depth of the sediments overlying the Pleistocene terrace determined by Frazier (1967). Wetland losses were 


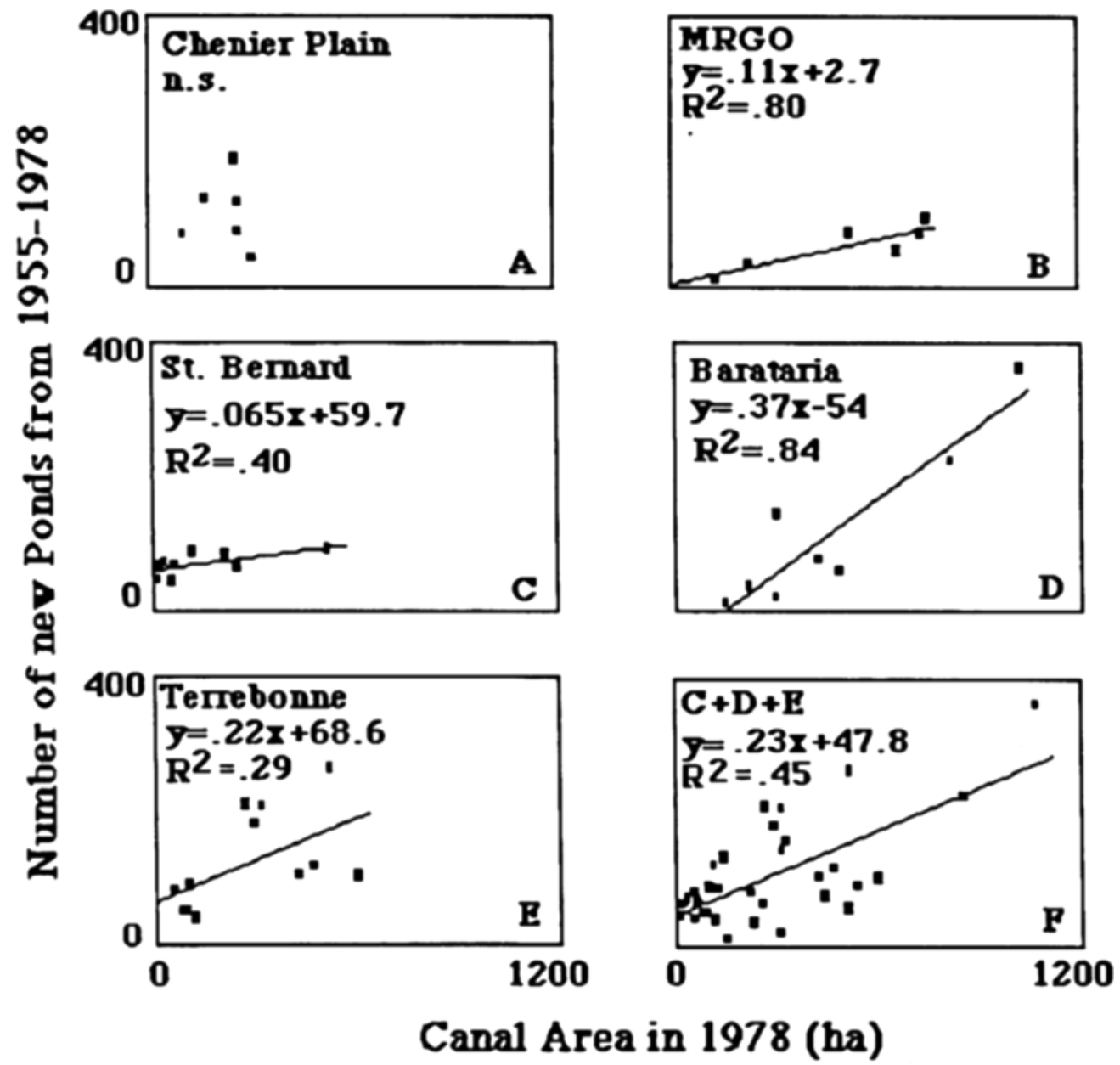

Fig. 7. The relationship between the number of new ponds $<20$ ha formed between $1955-56$ and 1978 and canal surface area (ha) for four study regions: MRGO is the Mississippi River Gulf Outlet running north/south through the St. Bernard delta; St. Bernard is a former delta of the Mississippi River, on the eastern border of that river; Barataria is the hydrologic unit just west of the Mississippi River; Terrebonne is the hydrologic unit on the western border of the Barataria hydrologic unit; the Chenier Plain is the western one-third of the Louisiana coastal zone.

high, or low, where sediment thickness was high, or low, respectively, presumably due to regional differences in geologic subsidence. The implication is that higher rates of subsidence should lead to more, not less, pond formation, all other factors being equal.

Canals and their spoil banks are directly related to wetland-to-water conversion and it is evident as far as $2 \mathrm{~km}$ away from those canals. This is clear from the distance versus frequency plot for two different pond sizes, by visual examination of the many maps of pond formation, and from the relationships between pond formation and canal density whose intercept is near zero.

There are at least two possible implications of these relationships: (1) there are common factors relating canal area to the net change in land-toopen water, or (2) the relationship is spurious. We assume it is not the latter because of the high num- ber of data points ( $>7,800$ new ponds; 72 maps), broad areal coverage, and known mechanisms to explain the apparent coupling.

We suggest, therefore, that these results support the hypothesis that the hydrologic impacts of canals and spoil banks affect wetland-to-water conversion $2-3 \mathrm{~km}$ away from canals, are directly related (as a causal agent) to the majority of wetland losses in the study area, and their impacts vary regionally, for example, with sediment compaction rates that increase with increasing sediment deposition. 'This is a regional study, not a local study, so the results apply only on a broad scale. This study area includes major sections of all the regional groupings described in Scaife et al. (1983) and Cowan and Turner (1989) and does not differ substantially from the general results of that modeling study in that regional differences and the same influences of geological substrate are dem- 

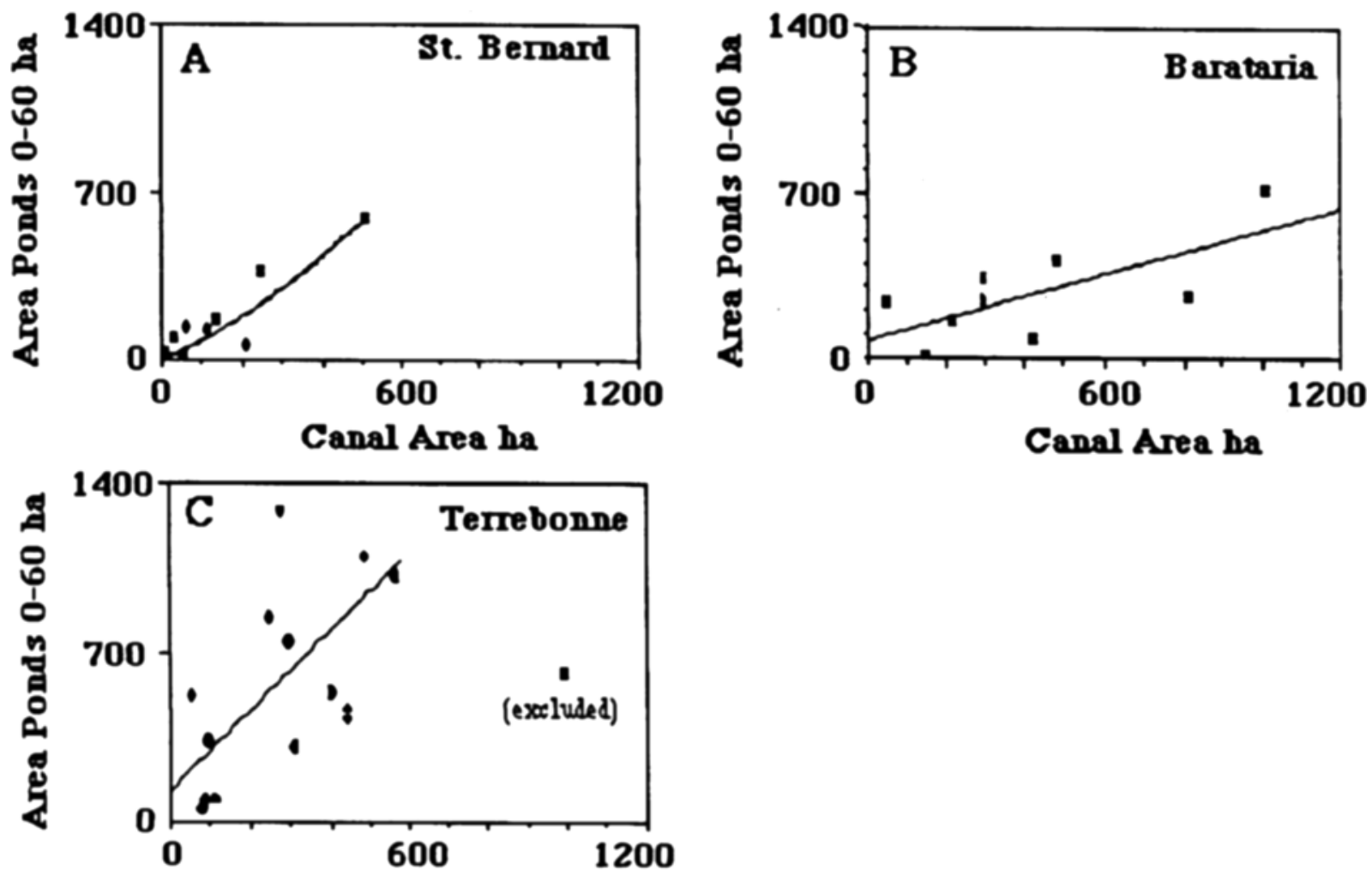

Canal Area ha

Fig. 8. The relationship between the net gain in ponds $<60$ ha formed between 1955-56 and 1978 and canal surface area (ha) for the study region. St. Bernard (A) is a former delta of the Mississippi River, on the eastern border of that river; Barataria (B) is the hydrologic unit just west of the Mississippi River; Terrebonne (C) is the hydrologic unit on the western border of the Barataria hydrologic unit.

onstrated influences on the overall regional wetland loss rates. It does not include all parts of some areas near the Atchafalaya River or the western side of Bayou Lafourche. We know of no data analysis which contradicts the conclusion that the marsh is breaking up rather than eroding, except at barrier islands.

\section{ACKNOWLEDGMENTS}

This work was supported by a contract with the Minerals Management Service, U.S. Department of Interior. H. Streiffer and $D$. Braud helped us learn the computer programing routines. J. Donley helped prepare the manuscript which benefits from the critical reviews of D. Cahoon, J. Cowan, N. Froomer, and S. Leibowitz.

\section{Literature Cited}

Baumann, R. H. ANd R. E. 'I'URner. In press. Direct Impacts of Outer Continental Shelf Activities on Wetland loss in the central Gulf of Mexico. Environmental Geology and Water Science.

Cowan, J. AND R. E. Turner. 1989. Modeling wetland loss in coastal Louisiana: Geology, geography, and human modifications. Environmental Management 12:827-838.
Cowardin, L. M., V. Carter, F. G. Golet, and E. T. LaRoe. 1979. Classification of wetlands and deepwater habitats of the United States. U.S. Fish and Wildlife Service, FWS/OBS79/31. Washington, D. C. 103 p.

Craig, N. J., R. E. Turner, and J. W. Day, Jr. 1980. Wetlands losses and their consequences in coastal Louisiana. Zeitschrift für Geomorphologie Neue Folge (Supl.). 34:225-241.

Frazier, D. E. 1967. Recent deltaic deposits of the Mississippi River, their development and chronology. Transactions Gulf Coast Association of Geological Societies 17:287-315.

KESEL, R. H. 1988. The decline in the suspended load of the lower Mississippi River and its influence on adjacent wetlands. Environmental Geology and Water Science 11:271-281.

Meade, R. H. ANd R. S. Parker. 1985. Sediments in Rivers of the United States. National Water Supply Summary. U.S. Geological Survey Water-Supply Paper 2275. 467 p.

SCAife, W. B., R. E. Turner, AND R. Costanza. 1983. Recent land loss and canal impacts in coastal Louisiana. Environmental Management 7:433-442.

Swenson, E. M. And R. E. Turner. 1987. Spoil banks: Effects on coastal marsh water level regime. Estuarine, Coastal Shelf Science 24:599-609.

Turner, R. E. 1985. Coastal land loss, canals and canal levee relations in Louisiana. U.S. Fish and Wildlife Service, Office of Biological Services, FWS/OBS 85/14.58 p.

TuRner, R. F. AND D. R. CAHOON (EDs.). 1987. Causes of Wetland Loss in the Coastal Central Gulf of Mexico. Vol. 1. 
Executive Summary, Vol. 2. Technical Narrative, Vol. 3. Appendices. Final report submitted to Minerals Management Service, New Orleans, Louisiana. Contract No. 14-12-00130252. OCS Study/MMS 87-0119. $536 \mathrm{p}$.

TURNeR, R. E. AND C. NeILl. 1984. Revisiting impounded wetlands after 70 years, p. 309-322. In R. J. Varnel (ed.), Proc. Water Quality and Wetlands Management Conference. Louisiana Environmental Professionals Association New Orleans, Louisiana.

W alker, H. J., J. M. Coleman, H. H. Roberts, and R. S. Tye. 1987. Wetland loss in Louisiana. Geografiska Annaler 69A: 189-200.

Wicker, K. M. 1980. Mississippi Deltaic Plain Region Ecolog- ical Characterization: A Habitat Mapping Study. A User's Guide to the Habitat Maps. U.S. Fish and Wildlife Service, Office of Biological Scrvices, FWS/OBS-79/07. Slidell, Louisiana. $45 \mathrm{p}$, appendices, 464 maps.

WiCker, K. M. 1981. Chenier Plain Region Ecological Characterization: A Habitat Mapping Study. A User's Guide to the Habitat Maps. Louisiana Coastal Resources Program, Louisiana Department of Natural Resources. Baton Rouge, Louisiana. 45 p, appendices, 53 maps.

Received for consideration, January 22, 1988 Accepled for publication, October 5, 1989 